\title{
Marketing Sharia, Customer Satisfaction, Religiosity, Financing, and Customer Loyalty
}

\author{
Evi Rahmawati ${ }^{1, *}$ Aleti N. Pratiwi ${ }^{1}$ \\ ${ }^{1}$ Universitas Muhammadiyah Yogyakarta, Indonesia \\ *Corresponding author. Email: erahmawati77@gmail.com
}

\begin{abstract}
This research aims to analyze the effect of sharia marketing, customer satisfaction, cooperative image, religiosity, service quality, and financing cost on customer loyalty. The sample of this study is Sharia Cooperatives in Sleman District. This study sample comprises of 44 respondents. The results shows that customer satisfaction and financing costs affected customer loyalty, while cooperative image, religiosity, service quality, and sharia marketing did not affect customer loyalty.
\end{abstract}

Keywords: Marketing Sharia, Financing, Religiosity, Customer Loyalty.

\section{INTRODUCTION}

A financial institution is always competing in order to survive to achieve the intended goals. As a cooperative of non-bank financial institutions, Islamic cooperatives do not only compete with non-bank institutions but also with other financial institutions. Sharia cooperatives are relatively new than banking, so they have a high level of difficulty in facing competition. Thus, Islamic cooperatives strive to retain customers as one of the strategies for their sustainability [4].

Sharia cooperatives are part of sharia financial institutions engaged in channeling and collecting funds on a micro basis. In the raising fund context, Islamic cooperatives will compete to collect funds from the community, where this source is used for funding for sharia cooperative businesses. Besides, Islamic cooperatives also compete for financing customers. Customers who will carry out financing do personal finance by considering several things: the ease of financing systems, financing procedures, financing period, the number of installments, the service convenience factor, and location. Then, Islamic cooperatives can provide the information needed by customers so that they can ensure that the financial services of Islamic cooperatives are considered appropriate [4].

Along with the development of increasingly advanced Islamic financial institutions, it has resulted in a large number of financial institutions that provide benefits, allowing people to choose the best because they can sort out various lists of financial institutions. However, financial institutions in the form of Islamic cooperatives have not experienced significant growth compared to Islamic banking. Sharia cooperatives in DIY, according to data from the DIY Department of Cooperatives and SMEs in 2016, totaled 318 cooperatives; in 2017, there were 292 cooperatives; in 2018, there were 268 cooperatives; in 2019, there were 239 cooperatives. From this data, it is known that Islamic cooperatives have decreased every year starting from 2016, meaning that there are problems, one of which results in a reduced number of customers due to the lack of a supervisory board, poor service, disloyal customers, news about customer fraud, and others [6].

Sharia cooperatives are engaged in services, so customers are the assets. It can be interpreted that customers are essential for Sharia cooperatives' sustainability. Therefore, Islamic cooperatives must have various strategies to retain customers and attract new customers who can consistently use their services. Methods that can be used to create customer loyalty are improving service quality, customer satisfaction, corporate image, financing costs, and sharia marketing, as in previous research conducted by [14], [13], [9], and [5].

\section{LITERATURE REVIEW AND HYPOTHESIS DEVELOPMENT}

\section{Marketing Syariah And Customer Loyalty Style Palette}

Sharia marketing is a scientific discipline that has four elements: product, price, place, and promotion in accordance with Islamic principles. Within these four 
elements, there are religious values to benefit customers who do not hesitate to use sharia cooperative services [14]. Research [13] states that the strategic business discipline directs the process of creating, offering, and changing the value of a producer or company or individual to others and in the whole process in accordance with the contract and business principles in Islam.

It is in line with stakeholder theory, in which an entity operates not only for its business interests but for other parties. When the Islamic cooperative is maximally in terms of sharia marketing to please customers, the customer will feel satisfied and loyal. Therefore, Sharia marketing can be positively associated with customer loyalty. Previous studies have found that Sharia marketing positively affected customer loyalty [14] and [17].

H1: Sharia Marketing has a positive effect on Customer Loyalty

\section{Customer Satisfaction and Customer Loyalty}

According to [3], customer satisfaction is a measure in terms of products, services, and others, which exist in a company that can exceed or meet customer expectations. When a customer feels that his expectation has been achieved, an emotion will emerge that the customer has been served and treated, particularly by the company, making the customer continue to use products from the organization.

Customers are satisfied when the product or service obtained provides something they are looking for to a sufficient level based on how much their expectations; therefore when the performance is as expected, the satisfied customer will provide benefits for the Islamic cooperative by advising friends and saying positively about Islamic cooperatives [13]. Customers are crucial for the service sector sustainability, including sharia cooperatives, even though customer satisfaction is based on perceptions of the services received [5]. It is in line with the perception theory, which is the view of the service received. Customer satisfaction is dynamic, depending on the service received with customers' expectations in mind. Research [3], [5], and [13] found that satisfaction had a positive effect on customer loyalty.

H2: Customer Satisfaction has a positive effect on Customer Loyalty

\section{Cooperative Image and Customer Loyalty}

The cooperative image represents a sharia cooperative as a whole, which raises customers' perceptions of what kind of sharia cooperative they want to achieve and how it is in a position at the time above in the company. One of the company's image effects is representing a company. The company's image must be built as well as possible because it can be a concern for both prospective customers and customers to stay with the entity [11]. It is in line with the perception theory, which can cause an image to be formed in accordance with the Islamic cooperatives' conditions.
The cooperative image can influence the public's perception. When Islamic cooperatives can create positive perceptions in terms of products and services, customers will also be committed and rely on Islamic cooperatives. Cooperate image had a positive effect on customer loyalty, as supported by research [11], [16] and [17].

H3: Corporate image has a positive effect on Customer Loyalty

\section{Religiosity and Customer Loyalty}

Religiosity is a basis that must be owned to behave. In Islam, ethics or morals are the results of faith, Islam, and piety based on the belief in a trusted God. Religiosity had a great influence on one's religion [18].

Sharia cooperatives have business principles to be implemented in accordance with Islamic law, which is sourced from the Koran and As Sunnah that should benefit sharia customers and cooperatives [2]. It is in line with stakeholder theory, where Islamic cooperatives benefit their business and customers. The benefits obtained are material and non-material so that the customer has a balance between the world and the hereafter that causes someone to choose to use Islamic cooperatives.

Research [18] concluded that most sharia cooperative customers are Muslims who usually live their lives to achieve happiness in both the world and the hereafter. Therefore, they have the commitment and purpose of continuing to choose sharia cooperatives. Previous studies [18] and [2] revealed that religiosity positively affected customer loyalty.

H4: Religiosity has a positive effect on Customer Loyalty

\section{Service Quality and Customer Loyalty}

Service quality is a phase of good or bad service conditions provided by a sharia cooperative to satisfy consumers or customers by providing services that exceed consumer expectations. When Islamic cooperatives can meet customer expectations, customers can survive, which creates the perception that the services provided are good [1]. It is in line with the perception theory, where the customer's view is in accordance with the services provided so that between customers have different perceptions of how big the imagined expectations are. If the facts exceed the customer's expectations, it can be said that the service is good. If the service quality provided is good, customers can make repurchases or be consistent with sharia cooperatives. Research [1], [8], and [15] uncovered that service quality had a positive effect on customer loyalty. Loyalty

H5: Service Quality has a positive effect on Customer 


\section{Financing Cost and Customer Loyalty}

The financing cost is based on Islamic principles, including not containing elements of usury, gharar, fraud, and others. The agreed financing cost between the customer and the Islamic cooperative has relatively the same value at all times and is in accordance with other customers' conditions. It is in line with the stakeholder theory, where it is not only for one's benefit but thinking about the customer's ability to pay. Therefore, the financing cost can be used as a strategy for becoming a customer of sharia operations. When the financial cost felt by the customer is beneficial, a committed relationship can be established between the Islamic cooperative and customer loyalty. Previous studies have found that financing cost positively affected customer [9].

H6: Financing Cost has a positive effect on Customer Loyalty

\section{RESEARCH RESULTS AND DISCUSSION}

This research was conducted in 10 Islamic cooperatives in Sleman Regency with the distribution map shown in Table 1:

Table 1. Questionnaire distribution data

\begin{tabular}{|c|c|c|c|}
\hline No & Name of Sharia Cooperative & Distributed questionnaires & Questionnaire returned \\
\hline 1. & $\begin{array}{l}\text { Koperasi Jasa Keuangan Syariah BMT } \\
\text { Turi Sembada [BMT Turi Sembada Sharia Financial } \\
\text { Services Cooperative] }\end{array}$ & 10 & 10 \\
\hline 2. & $\begin{array}{l}\text { Koperasi Syariah Serba Usaha Baitul } \\
\text { Maal Wa Tamwil Mitra Usaha Mulia [BMT Mitra Usaha } \\
\text { Mulia Multipurpose Sharia Cooperative] }\end{array}$ & 10 & 10 \\
\hline 3. & $\begin{array}{l}\text { Koperasi Simpan Pinjam dan Pembiayaan Syariah } \\
\text { Baitul Maal Wat Tamwl BMT Bening Suci [BMT Bening } \\
\text { Suci Savings and Loans and Sharia Financing Cooperative] }\end{array}$ & 10 & 10 \\
\hline 4. & $\begin{array}{l}\text { Koperasi Serba Usaha Syariah BMT } \\
\text { Mitra Amanah [BMT Mitra Amanah Sharia Multipurpose } \\
\text { Cooperative] }\end{array}$ & 10 & 10 \\
\hline 5. & $\begin{array}{l}\text { Koperasi Simpan Pinjam dan Pembiayaan Syariah Al } \\
\text { Ikhsan Mandiri Sejahtera [Al Ikhsan Mandiri Sejahtera } \\
\text { Sharia Savings and Loans and Financing Cooperative] }\end{array}$ & 10 & 4 \\
\hline 6. & $\begin{array}{l}\text { Koperasi Jasa Keuangan Syariah BMT Kube Sejahtera } 017 \\
{[\text { [BMT Kube Sejahtera } 017 \text { Sharia Financial Services }} \\
\text { Cooperative] }\end{array}$ & 10 & 3 \\
\hline 7. & $\begin{array}{l}\text { Koperasi Simpan Pinjam dan Pembiayaan Syariah Surya } \\
\text { Amanah Ummah [Surya Amanah Ummah Sharia Savings and } \\
\text { Loans and Financing Cooperatives] }\end{array}$ & 10 & 8 \\
\hline 8. & $\begin{array}{l}\text { Koperasi Serba Usaha Syariah BMT Bina Ummah [BMT } \\
\text { Bina Ummah Sharia Multipurpose Cooperative] }\end{array}$ & 10 & 9 \\
\hline 9. & $\begin{array}{l}\text { Koperasi Lembaga Keuangan Mikro } \\
\text { Syariah BWM Sunan Pandan Aran [Islamic Microfinance } \\
\text { Institution Cooperative BWM Sunan Pandanaran] }\end{array}$ & 10 & 5 \\
\hline 10 & $\begin{array}{l}\text { Koperasi Syariah Surya Mitra Ummat [Surya Mitra Ummat } \\
\text { Sharia Cooperative] }\end{array}$ & 10 & 3 \\
\hline
\end{tabular}


Table 2

Results

\begin{tabular}{|c|c|c|c|}
\hline Variable & Beta & T value & Sig \\
\hline $\begin{array}{c}\text { Sharia } \\
\text { Marketing }\end{array}$ & -.443 & -1.236 & .224 \\
\hline $\begin{array}{c}\text { Customer } \\
\text { Satisfaction }\end{array}$ & .579 & 2.096 & .043 \\
\hline $\begin{array}{c}\text { Cooperative } \\
\text { image }\end{array}$ & -.236 & -1.022 & .313 \\
\hline Religiosity & -.026 & -.197 & .845 \\
\hline $\begin{array}{c}\text { Service quality } \\
\text { Financing Cost }\end{array}$ & .177 & 1.456 & .154 \\
\hline
\end{tabular}

This study aims to examine and analyze the effect of Sharia marketing, customer satisfaction, cooperative image, religiosity, service quality, and financing cost on customer loyalty. This research was conducted at the Sharia Cooperative in Sleman Regency, DIY. Based on the testing and analysis conducted, it could be concluded from this study that Sharia marketing did not affect customer loyalty, Customer satisfaction had a positive effect on customer loyalty, The cooperative image did not affect customer loyalty, Religiosity did not affect customer loyalty, Service quality did not affect customer loyalty, Financing cost had a positive effect on customer loyalty.

For further research, it is hoped that the researcher can add other variables affecting customer loyalty, such as trust, competitor advantages, and others. Future research is expected to combine primary research with questionnaires and interview methods to reduce the respondents' possibility of answering non-objectively and increasing respondents' understanding of the statement items submitted. Besides, respondents' perceptions can be known in more depth, and the data obtained can be more representative.

\section{CONCLUSION}

This study analyzes the effect of sharia marketing, customer satisfaction, cooperative image, religiosity, service quality, and financing cost on customer loyalty. The sample of this study is Sharia Cooperatives and this study results shows that customer satisfaction and financing costs affects customer loyalty. This finding shows that the more customers are satisfies the more they will become loyal. Furthermore, the increase of financing costs also affects the customer loyalty. However, cooperative image, religiosity, service quality, and sharia marketing did not affect customer loyalty.

\section{REFERENCES}

[1] Asnawi, N., Sukoco, B. M., \& Fanani, M. A. (2019). The role of service quality within Indonesian customers satisfaction and loyalty and its impact on Islamic banks. Journal of Islamic Marketing, 11(1), 192-212. https://doi.org/10.1108/JIMA-03-2017-0033

[2] Chandra Kartika, Yusuf, F. H. (2019). Pengaruh Religiusitas, Trust, Corporate Image, dan Sistem Bagi Hasil Terhafap Customer Behavior Intention Menabung di Bank Syariah Mandiri Jawa Timur. 04(01), 30-49.

[3] El-Halaby, S., Hussainey, K., \& Abou-El-Sood, H. (2018). The non-economic consequences of disclosure in Islamic banks. International Journal of Emerging Markets, 13(6), 1948-1968

[4] Halimah, A. (2018). Peningkatan loyalitas Nasabah Tabungan Mudharabah melalui Pendekatan Syariah Marketing, Service Excellence, dan Reputasi. Journal of Finance and Islamic Banking, 1(1), 76-89

[5] Huzaimah, I. (2018). Analisis Etika Bisnis Islam Dan Pelanggan Dan Loyalitas Pelanggan. 04(April), 164190.

[6] Ismail, R., Syarikat, B., \& Batam, M. (2014). Nasabah Sebagai Prediktor Dalam Meningkatkan Loyalitas. Jurnal Organisasi Dan Manajemen, 10(2), 179-196.

[7] Kanya Prawitasari, \& Christine Tantrisna. (2016). Analisa Harapan Dan Persepsi Penumpang Terhadap Kualitas Makanan Yang Disediakan Oleh Maskapai Penerbangan Domestik Di Indonesia. Jurnal Manajemen Perhotelan, 2(1), 36-46.

[8] Kusuma Wijayanto. (2015). Pengaruh Kualitas Pelayanan Terhadap Kepuasan Dan Loyalitas 
Pelanggan Hardy'S Negara. Jurnal Paradigma, 17(01), 38-45.

[9] Kusumaramdhani, A., \& Fatimah, F. (2015). Pengaruh Reputasi Merk Dan Keadilan Bagi Hasil Terhadap Loyalitas Nasabah Tabungan Mudharabah Bank X Syariah Kcp Ciledug. Jurnal Ekonomi \& Bisnis PNJ, 14(1), 87-94.

[10] Munandar, J. M., Oktaviani, D., \& Angraini, Y. (2019). How important is CRM toward customer's loyalty to conventional and Islamic bank marketing strategy?: A case study from Indonesia. Journal of Islamic Marketing, (2014).

[11] Nawi, N. B. C., Al Mamun, A., Nasir, N. A. M., Abdullah, A., \& Mustapha, W. N. W. (2019).

[12] Brand image and consumer satisfaction towards Islamic travel packages. Brand Image and Consumer Satisfaction towards Islamic Travel Packages A Study on Tourism Entrepreneurship in Malaysia, 13(2), 188202.

[13] Nurhayati, N., \& Sukesti, F. (2017). Peningkatan Loyaltas Nasabah Bank Syariah Melalui Kualitas Layanan dan Kepuasan Nasabah dengan Variabel Religiusitas sebagai Variabel Moderating (Studi pada Bank Syariah di Kota Semarang). Economica: Jurnal Ekonomi Islam, 7(2), 141.
[14] Nurudin, N. (2017). Pengaruh Sharia Marketing terhadap Loyalitas Anggota KSPPS BMT Walisongo Semarang. MUQTASID Jurnal Ekonomi Dan Perbankan Syariah, 8(1), 40.

[15] Osaretin Kayode Omoregie, John Agyekum Addae, Stanley Coffie, George Oppong Appiagyei Ampong, K. S. O. (2019). Factors influencing consumer loyalty: evidence from the Ghanaian retail banking industry. International Journal of Bank Marketing, 37(3), 798820

[16] Subagia, I. K., \& Susanto, P. H. (2019b). Pengaruh Kualitas Pelayanan, Kepuasan Nasabah Dan Citra Perusahaan Terhadap Loyalitas Nasabah PT. Bank Central Asia Tbk Kantor Cabang Pondok Gede Plaza. Jurnal Manajemen Bisnis Krisnadwipayana, 7(1), 6984

[17] Setyono, L., Kusumawati, A., Mawardi, M. K., Kunci, K., Marketing, I., Perusahaan, C., ... Nasabah, L. (2015). The Effect of Islamic Marketing and Corporate Image on Customer Satisfaction and Customer Loyalty (Study on Customers of PT Bank Muamalat Indonesia Malang Branch Office). Jurnal Administrasi Bisnis, 27(1).

[18] Wijaya, I. F, Hakim, A. R., \& Saputro, N. (2019). Religiosity level and saving decisions in Baitul Maal wat Tamwil: the case of Indonesia 